\title{
CERVICAL NECROTIZING FASCIITIS DUE TO BACTERIAL TONSILLITIS
}

Bruno Zilberstein ${ }^{3}$, Roberto de Cleva ${ }^{1}$, Renato Scarsi Testa ${ }^{2}$, Ubirajara Sene ${ }^{1}$, Rony Eshkenazy ${ }^{3}$, and Joaquim José Gama-Rodrigues ${ }^{3}$

ZILBERSTEIN B et al. Cervical necrotizing fasciitis due to bacterial tonsillitis. CLINICS 60(2):177-182, 2005.

Necrotizing fasciitis is a severe and potentially fatal soft tissue infection, but involvement of the head and neck is rare. We report on 4 cases of cervical necrotizing fasciitis arising from tonsillitis. One patient was diabetic and one had received steroids before disease development. One patient developed acute respiratory failure and died of septic shock. Three patients recovered, helped by early recognition, aggressive surgical intervention, appropriate broad-spectrum antibiotics, and supportive therapy. The common bacteria found in all abscess samples were Streptococcus sp., but mixed flora with anaerobic organisms was seen in all but 1 case.

Tonsillitis and peritonsillar abscess must be suspected as a cause of cervical necrotizing fasciitis and a successful result can be achieved with immediate aggressive treatment.

KEYWORDS: Necrotizing fasciitis. Tonsillitis. Peritonsillar abscess.

Necrotizing fasciitis is a highly aggressive infectious process characterized by spreading along the fasciae planes. It can rapidly involve overlying skin, subcutaneous tissues, muscle, and other adjacent soft tissues structures. The most frequently involved areas are the thorax, limbs, perineum, abdomen, and groin. ${ }^{1,2}$ Increased numbers of cases of cervical necrotizing fasciitis have been reported in recent years. ${ }^{3,4,5}$ Cervical necrotizing fasciitis is characterized by cutaneous necrosis, suppurative fasciitis, thrombosis of small blood vessels in the subcutaneous tissue, and extreme systemic toxicity. It is a severe condition, with a high death risk, ${ }^{5}$ and prognosis is aggravated by spread of the infection through the fasciae, with development of mediastinitis and septic shock. Permanent mutilation and deformity of the face and submandibular area is a frequent complication.

The most common causes of cervical necrotizing fasciitis are dental infection (dental abscess, gingivitis, pulpits), ${ }^{1}$ blunt trauma, ${ }^{1}$ radiotherapy,${ }^{6}$ and necrotizing fasciitis

From the Department of Gastroenterology ${ }^{1}$ and the Divisions of Emergency Medicine $^{2}$ and Digestive Surgery ${ }^{3}$, Hospital das Clínicas, Faculty of Medicine, University of São Paulo - São Paulo/SP, Brazil.

E-mail: brunozilb@uol.com.br

Received for publication on September 02, 2004.

Accepted for publication on December 10, 2004. of unknown origin. ${ }^{7}$ Tonsillitis and peritonsillar abscesses are uncommon causes of necrotizing fasciitis. A literature review revealed only 13 cases with this etiology. ${ }^{8}$ Predisposing factors include diabetes mellitus, steroid administration, arteriosclerosis, chronic renal failure, hypothyroidism, obesity, alcoholism, cancer, cirrhosis, drug abuse, and a poor nutritional state, all involved with loss of host defenses. ${ }^{1,4}$ As it is a rare and unsuspected clinical condition, early diagnosis is not easy. We report on 4 cases of cervical necrotizing fasciitis arising from tonsillitis.

\section{CASE REPORTS}

\section{Case 1}

A 41-year-old diabetic man was admitted for treatment of painful swelling in his neck. The physical examination revealed bacterial tonsillitis and abscess (Figure 1). A contrast-enhanced CT scan of the neck showed diffuse enhancement of the superficial and deep cervical fasciae; thickening of the platysma, sternocleidomastoid, and strap muscles; as well as air and small fluid collections in multiple neck compartments (Figure 2). The patient underwent a tracheostomy followed by a bilateral anterior cervical incision 


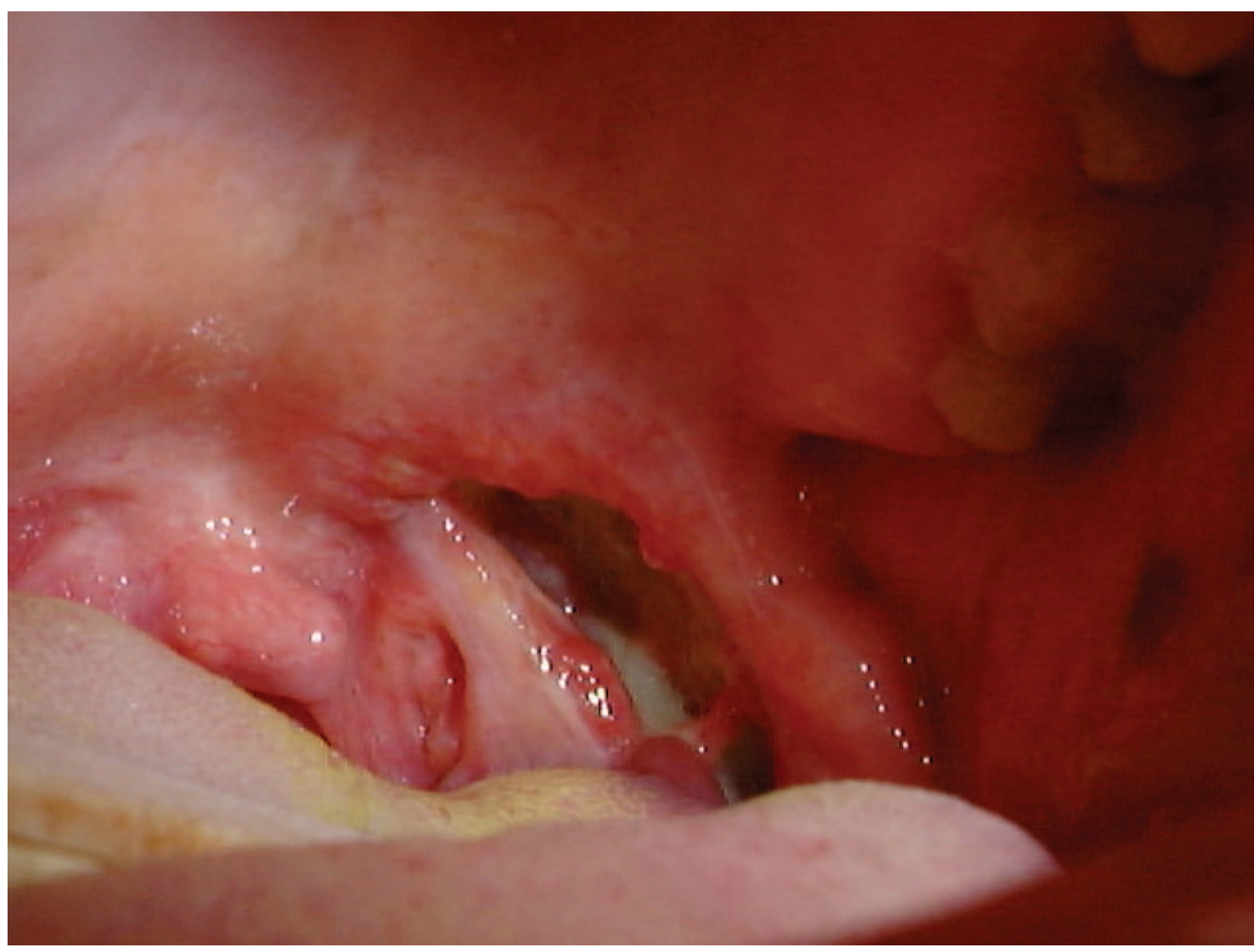

Figure 1 - Bacterial tonsillitis and abscess.

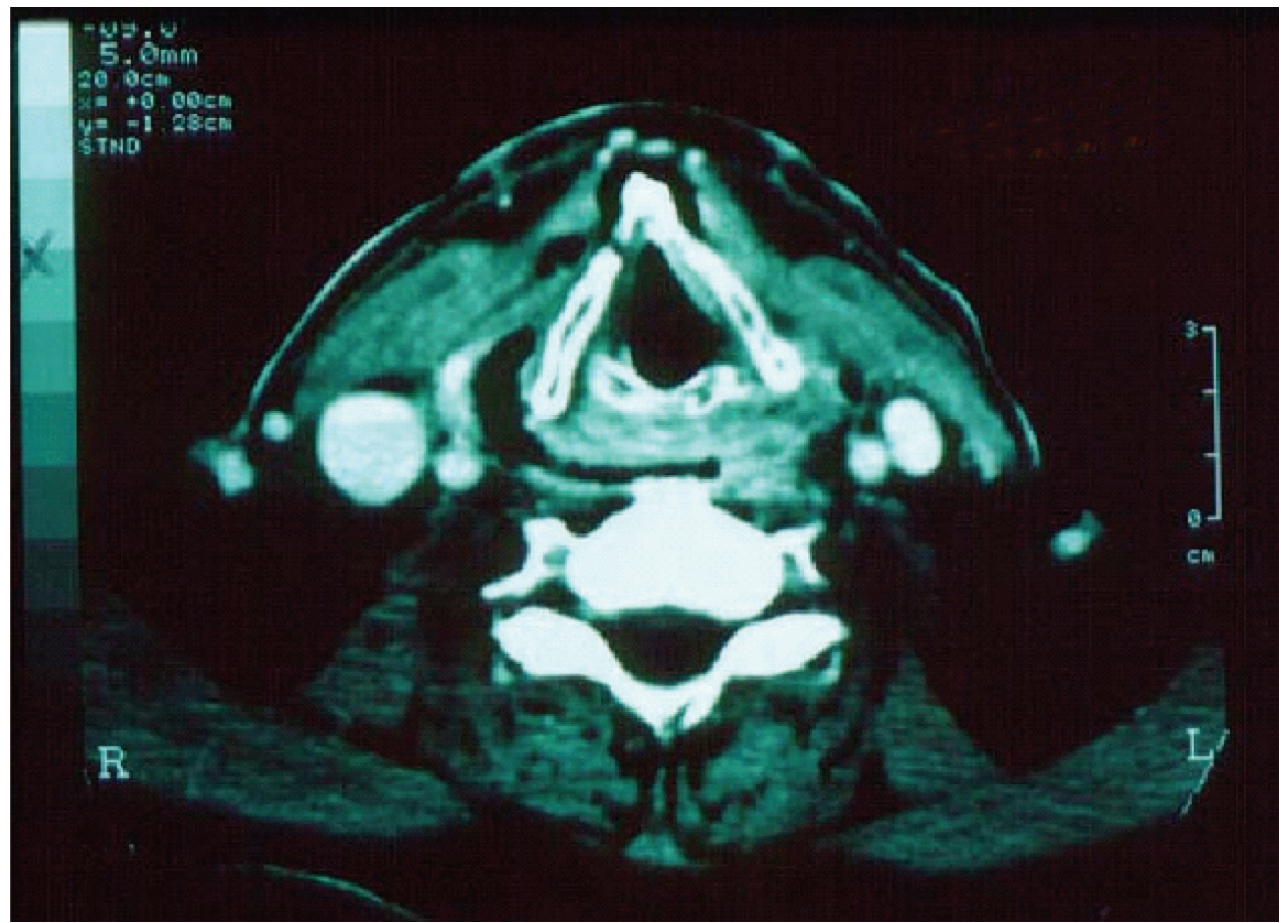

Figure 2 - Computed tomography of the neck showing diffuse thickening and infiltration of the cutis and subcutis; diffuse enhancement of the superficial and deep cervical fasciae; thickening of the platysma, sternocleidomastoid, and strap muscles; and air and small amounts of fluid buildup in multiple neck compartments. 
and extensive drainage of the neck. The platysma, superficial trap muscles, omothyroids, and sternocleidomastoid were removed. Subsequent culture revealed Streptococcus viridans, Peptostreptococcus anaerobius, Peptostreptococcus micros, and Clostridium bifermentans. The patient was successfully treated with ampicillin and metronidazole. He gradually improved and was discharged from the hospital 18 days after admission.

\section{Case 2}

A 62-year-old man was admitted to the hospital for treatment of severe dermatomyositis. He received prednisone 80 $\mathrm{mg} /$ day. On the $12^{\text {th }}$ hospital day he developed odynophagia and dysphagia. The physical examination revealed bacterial tonsillitis, fever, and a palpable mass in the right submandibular area. A CT scan showed diffuse enhancement of the superficial and deep right cervical fasciae; thickening of the platysma, sternocleidomastoid, and strap muscles; and air and small fluid collections in multiple neck compartments. A right lateral cervicotomy with extensive drainage was performed. Culture revealed S. viridans, and Peptostreptococcus anaerobius. The patient was treated with penicillin and metronidazole, but despite intensive care management, he developed mediastinitis and septic shock and died of multiple organ failure 8 days later.

\section{Case 3}

A 43-year-old man was admitted with tonsillitis and bilateral edema and erythema of the neck. He received cephalexin $2.0 \mathrm{gr}$. and sodium diclofenac for 3 days before admission, without improvement. A CT scan showed multiple collections of air in the cervical region, without involvement of the upper mediastinum. The patient underwent bilateral cervical drainage through a midcervical incision. Culture revealed $S$. viridans and Clostridium sp. The patient was treated with penicillin and metronidazole and discharged 11 days after admission.

\section{Case 4}

A 40-year-old woman was admitted with tonsillitis, edema of the left neck, and trismus. The physical examination revealed a palpable mass in the left submandibular area suggestive of a cervical abscess. A CT scan showed fluid collections with air in the left cervical region. A left anterolateral cervicotomy with drainage was performed. Culture revealed $S$. viridans and Corynebacterium $s p$. The patient was treated with penicillin and metronidazole and discharged after 23 days.

\section{DISCUSSION}

Cervical necrotizing fasciitis was defined by Monreland et al. ${ }^{9}$ and modified later to include infections beyond the submandibular space as follows: (1) inflammation in the submandibular space, with little or no suppuration and with spread to the neck beyond the level of the hyoid bone; (2) involvement of more than one neck space, usually bilateral; (3) tissue necrosis with serosanguineous, putrid infiltration; (4) involvement of connective tissue and fasciae and secondary in muscles and skin, but not of glandular structures; and (5) contiguous—not lymphatic-spread.

Klabacha et al. ${ }^{10}$ proposed staging these inflammatory processes as follows: type I-suppuration infection confined to the epidermis; type II-infection extending to the dermis; type III-infection extending to the superficial musculoaponeurotic layer of the face and superficial layer of the deep cervical fascia; type IV-infection extending to the musculature.

Normally, infection progresses rapidly and can involve the vascular structures causing small vessel thromboses. Necrotizing fasciitis of the head and neck usually results from polymorphic flora including numerous bacilli and cocci and occurs around the scalp and facial areas or primarily in the neck. In a series of 45 cases, ${ }^{3}$ anaerobes were isolated in 32 cases $(71 \%)$. Anaerobes only were isolated in 10 cases $(22 \%)$, while a mixture of anaerobic and aerobic organisms were found in 22 cases $(49 \%)$. Aerobic bacteria were only found in 3 patients (7\%). Streptococcus sp. were found in 8 cases. In a study of 20 cases, ${ }^{11}$ polymorphic flora were also found, with aerobic gram positive cocci isolated in 18 cases and anaerobic flora in 11. Streptococcus sp. were found in 6 . In this group, a mixed aerobic and anaerobic flora was identified, with a prevalence of Streptococcus sp.

Mortality for this condition have been reported to be $22 \%(10 \text { of } 45)^{3}$ and $50 \%^{12}$ but it has been decreasing in recent years due to early diagnosis and advanced treatment in intensive care units. Even so, 1 patient in our 4 cases died $(25 \%)$.

The most common clinical presentations are painful edema, erythema, warmth, tenderness, crepitation, and submandibular abscess. Patients can develop mediastinitis and consequent septic shock.

Fasciitis is generally due to a dental or pharyngeal abscess (surgical or post-traumatic), ${ }^{3,11}$ radiotherapy, ${ }^{6}$ or unknown ori$\left.\operatorname{gin}^{7}\right)$. Tonsillar origin is rare; nevertheless, tonsillitis must be suspected as a possible cause of cervical necrotizing fasciitis to promote a prompt therapeutic action. Patients usually have an associated systemic condition such as diabetes mellitus, arteriosclerosis, obesity, metastatic neoplasm, chronic renal fail- 
ure, old age, hypothyroidism, alcoholism, neoplasms, cirrhosis, drug abuse, poor nutritional state, or use of corticosteroids. ${ }^{1,4,11}$ In our patients, 2 out 4 had immunosuppressive conditions due to diabetes and corticosteroid use.

The divisions and subdivisions of the deep cervical fasciae determine the limits and the spread of the infectious process. Nevertheless, it is difficult to detect this infection before it has spread to the deep fasciae, when complications are more frequent.

Complications of cervical necrotizing fasciitis include airway obstruction, pneumonia, pulmonary abscess, septic shock, jugular venous thrombophlebitis, and mediastinitis. In order to exclude the cervical necrotizing fasciitis diagnosis, x-ray of the affected area must reveal an absence of gas in the soft tissue. CT scan has been advocated for detecting gas, identifying the spread of infection in vascular sheaths, and detecting the extension of infection to remote areas (mediastinitis and pleural or pericardial effusions). ${ }^{13}$

Effective treatment and management of cervical necrotizing fasciitis is based on early recognition, aggressive surgical intervention, use of broad-spectrum antibiotics, and supportive therapy. It is important to explore and drain all involved fascial planes. To carry out an adequate, wide, extensive fasciotomy with exposure and exploration of all compartments, the surgeon must understand the complex anatomy of the cervical fasciae and deep neck spaces. ${ }^{14}$ This was promptly performed in our patients with good results in 3 of 4 patients. In 1 patient, in spite of adequate surgical treatment and appropriate antibiotic coverage, the infection spread rapidly to the mediastinum.

Other therapeutic considerations include management of hypocalcemia, anemia, and hypovolemia. Hypocalcemia results from the combination of ionic calcium with fatty acids from fat necrosis, forming an insoluble soap. Intravenous calcium replacement may be required. Hemolysis of erythrocytes occurs from the actions of bacterial enzymes and can result in anemia that may require transfusion. ${ }^{11}$ Fluid from extracellular edema usually occurs and requires crystalloid replacement.

In necrotizing fasciitis, the synergistic action of anaerobic and facultative bacteria in a hypoxic environment promotes the production of destructive tissue enzymes and endotoxins that suppress host defenses, resulting in local and systemic dissemination of infection. Hyperbaric oxygen has been reported to be an effective adjuvant therapy to antibiotics and surgery in the treatment of necrotizing fasciitis of the extremities and trunk, with a mortality rate of $23 \%$ in the group receiving hyperbaric oxygen versus $66 \%$ in the group without hyperbaric oxygen. ${ }^{15}$ In another study, the use of adjuvant hyperbaric oxygen therapy with an aggressive surgical approach and broad-spectrum intravenous antibiotics in 12 patients with cervical necrotizing fasciitis produced good results. ${ }^{15,16}$ Hyperbaric oxygen therapy was not considered for our patients because of the quick response to surgery and antibiotics of 3 of them and the rapid evolution of the deceased patient.

Table 1 - Review of all cases found in literature ${ }^{8}$.

\begin{tabular}{|c|c|c|c|c|c|c|}
\hline Author/year & $\mathrm{N}$ & Cultures & Associated diseases & Complications & Antibiotics & Outcome \\
\hline Wenig 1984 & 2 & $\begin{array}{l}\text { SH, FN, BM, EL, } \\
\text { PA, SS, SF, BF, CS }\end{array}$ & $\mathrm{DM}$ & $\begin{array}{l}\text { Thoracic and jugular } \\
\text { vein thrombosis }\end{array}$ & $\mathrm{P}, \mathrm{Cl}, \mathrm{G}, \mathrm{C}, \mathrm{CH}$ & Both died \\
\hline Lalwani 1991 & 2 & SH, MAF,BM & - & Mediastinal and thoracic & $\mathrm{C}, \mathrm{M}, \mathrm{P}$ & Both survived \\
\hline Tovi 1991 & 1 & $\mathrm{E}, \mathrm{PM}, \mathrm{KP}$ & - & $\begin{array}{l}\text { Meningitis, mediastinitis, } \\
\text { and lung abscess }\end{array}$ & INA & Died \\
\hline Scott 1994 & 1 & SM, MAF & - & Mandible necrosis & $\mathrm{C}, \mathrm{F}, \mathrm{M}, \mathrm{P}$ & Survived \\
\hline Greinwald 1995 & 1 & SE & $\mathrm{DM}$ & Thoracic & AS, I & Survived \\
\hline Yii 1996 & 1 & SM, MAF & $\mathrm{DM}$ & $\begin{array}{l}\text { Thoracic and pharyngeal } \\
\text { perforation }\end{array}$ & $\mathrm{P}, \mathrm{F}, \mathrm{M}, \mathrm{G}$ & Survived \\
\hline Skitarelic 1999 & 1 & SE, SH & - & - & AS, G, I & Survived \\
\hline Djupesland 2000 & 3 & SH, SM, BM & $\mathrm{B}$ & Mediastinal and thoracic & $\mathrm{P}, \mathrm{M}, \mathrm{T}$ & 1 died, 2 survived \\
\hline Skitarelic 2003 & 1 & SE & - & - & $\mathrm{P}, \mathrm{AS}, \mathrm{G}, \mathrm{I}$ & Survived \\
\hline TOTAL & 13 & & & & & $\begin{array}{l}5 \text { died }(24 \%) \\
12 \text { survived }\end{array}$ \\
\hline
\end{tabular}

Cultures: SH - Streptococcus hemolyticus, FN - Fusobacterium nucleatum, BM - Bacteroides melaninogenicus, EL - Eubacterium lentum, PA - Peptostreptococcus anaerobius, SS - Streptococcus sanguis, SF - Streptococcus faecalis, SV - Streptococcus viridans, BF Bacteroides fragilis, CS - Corynebacterium sp., MAF - Mixed anaerobic flora, E - Enterobacter, PM - Proteus mirabilis, KP - Klebsiella pneumoniae, SE - Staphylococcus epidermidis, SM - Staphylococcus milleri, CL - Clostridium sp. Antibiotics: P - penicillin, G gentamicin, $\mathrm{Cl}$ - clindamycin, $\mathrm{C}$ - cefazolin, $\mathrm{CH}$ - chloramphenicol, $\mathrm{M}$ - metronidazole, AS - ampicillin/sulbactam, I - imipenem sodium, $\mathrm{F}$ - flucloxacillin, T - tobramycin, A - ampicillin, INA - Information not available. DM - diabetes mellitus, B - Bechterew's disease, D dermatomyositis 
Tonsillitis and peritonsillar abscesses are uncommon causes of cervical necrotizing fasciitis, with only 13 cases reported in literature ${ }^{8}$ (Table 1). We report on 4 patients with cervical necrotizing fasciitis due to tonsillitis occurring within 8 months. One patient was diabetic and 2 were receiving steroidal or nonsteroidal anti-inflammatory agents. One patient developed acute respiratory distress syndrome requiring mechanical ventilation and presented septic shock due to spread of infection to the mediastinum. Three patients recovered because of early diagnosis, aggressive surgical intervention, use of appropriated broad-spectrum antibiotics, and supportive therapy.

We conclude that tonsillitis and peritonsillar abscesses must be considered as putative causes of cervical necrotizing fasciitis and that early and adequate surgical drainage associated with broad-spectrum antibiotics should be the treatment of choice for these patients.

\section{RESUMO}

ZILBERSTEIN B e col. Fasceite necrotizante cervical secundária a amigdalite bacteriana. CLINICS 60(2): 177-182, 2005.

A fasceite necrotizante cervical é uma infecção grave de partes moles do pescoço. Trata-se de entidade rara, porém quando presente tem como principal origem um foco infeccioso odontogênico. São descritos 4 casos de fasceite necrotizante cervical a partir de tonsilites e abscesso peritonsilar, os quais, foram admitidos e tratados na unidade de terapia intensiva. Um dos pacientes era portador de Diabetes Melittus não insulino- dependente e outro paciente havia recebido corticoterapia antes do desenvolvimento da infecção. Em um dos casos ocorreu mediastinite, in- suficiência respiratória e o paciente evolui para o óbito em decorrência de choque séptico. Durante o tratamento, 3 pacientes evoluíram satisfatoriamente devido ao diagnostico precoce, tratamento cirúrgico agressivo e utilização de antibiótico terapia de largo espectro. A bactéria mais comumente encontrada foi o Streptococcus sp, mas flora mista com germes anaeróbios foi encontrada em 3 dos casos descritos.

CONCLUSÕES: Deve-se suspeitar de tonsilite e abscesso peritonsilar como causa de fasceite necrotizante cervical para que tratamento agressivo e precoce seja realizado.

UNITERMOS: Fasceite necrotizante cervical. Tonsilite. Abscesso peritonsilar. 


\section{REFERENCES}

1. Aimioni C, Cilione A R, Grandi E, Lombardi L, Merlo R, Pastore A. Cervical necrotizing fasciitis. Eur Arch. Otorhinolaryngol 1999;256:510-3.

2. Reed JM, Anand VK. Odontogenic cervical necrotizing fasciitis with intrathoracic extension. Otolaryngology - Head and Neck Surgery 1992;107:596-600.

3. Mathieu D, Neviere R, Teillon C, Chagnon JL. Cervical necrotizing fasciitis: clinical manifestations and management. Clin Infect Dis 1995;21:51-6.

4. Kantu S, Harl-EL G. Cervical necrotizing fasciitis. Ann Otol Rhinol Laryngol 1997;106:965-70.

5. Ferri E, Ianniello F, Salandin S. Necrotizing fasciitis of the neck in a patient with acute myeloid leukemia: clinical features, therapeutic strategy and review of the literature. Acta Otorhinolaryngol Ital 1998;18:116-22.

6. Mortimore S, Thorp M. Cervical necrotizing fasciitis and radiotherapy: a report of two cases. J Laryngol Otol 1998;112:298-300

7. Gillis AR, Gillis TM. Necrotizing cervical fasciitis of unknown origin. J Otolaryngol 1992;21:171-3.

8. Skitarelic N, Mladina M, Morovic M, Skitarelic N. Cervical necrotizing fasciitis: sources and outcomes. Infection 2003;31(1):39-44.

9. Moreland LW, Corey J, Mackenzie R. Ludwig's angina: case report and review of the literature. Arch Intern Med 1988;148:461-6.
10. Klabacha ME, Stankiewicz JA, Clift SE. Severe soft tissue infection of the face and neck: A classification. Laryngoscope 1982;92:1135-9.

11. Mohammedi I, Ceruse P, Duperret S, Vedrinne JM. Cervical necrotizing fasciitis: 10 years experience at a single institution. Intens Care Med 1999;25:829-34.

12. Krespi YP, Lawson W, Blaugund SM, Biller HF. Massive necrotizing fasciitis infections of the neck. Head Neck Surg 1981;3:47581.

13. Becker M, Zbaren P, Hermans R, Becker CD, Marchal F, Kurt AM, et al. Necrotizing fasciitis of the head and neck: role of computed tomography in diagnosis and management. Radiology 1997;202:471-6.

14. Durazzo MD, Pinto FR, da Rocha Loures MS et al. Os espaços cervicais profundos e seu interesse nas infecções da região. Rev Ass Med Bras 1997;43:119-26.

15. Risman J, Zamboni AZ, Curtis A, Graham DR, Konrad HR, Ross DS. Hyperbaric oxygen therapy for necrotizing fasciitis reduces mortality and need for debridements. Surgery 1990;108: 84750 .

16. Whitesides L, Cotto-Cumba C, Myers RA. Cervical necrotizing fasciitis of odontogenic origin: a case report and review of 12 cases. J Oral Maxillofac Surg 2000;58:144-51. 